\title{
Elusive citizenship
}

Citation for published version (APA):

Vink, M. (2015). Elusive citizenship. Maastricht University. https://doi.org/10.26481/spe.20150501mv

Document status and date:

Published: 01/05/2015

DOI:

10.26481/spe.20150501mv

Document Version:

Publisher's PDF, also known as Version of record

\section{Please check the document version of this publication:}

- A submitted manuscript is the version of the article upon submission and before peer-review. There can be important differences between the submitted version and the official published version of record.

People interested in the research are advised to contact the author for the final version of the publication, or visit the DOI to the publisher's website.

- The final author version and the galley proof are versions of the publication after peer review.

- The final published version features the final layout of the paper including the volume, issue and page numbers.

Link to publication

\footnotetext{
General rights rights.

- You may freely distribute the URL identifying the publication in the public portal. please follow below link for the End User Agreement:

www.umlib.nl/taverne-license

Take down policy

If you believe that this document breaches copyright please contact us at:

repository@maastrichtuniversity.nl

providing details and we will investigate your claim.
}

Copyright and moral rights for the publications made accessible in the public portal are retained by the authors and/or other copyright owners and it is a condition of accessing publications that users recognise and abide by the legal requirements associated with these

- Users may download and print one copy of any publication from the public portal for the purpose of private study or research.

- You may not further distribute the material or use it for any profit-making activity or commercial gain

If the publication is distributed under the terms of Article $25 \mathrm{fa}$ of the Dutch Copyright Act, indicated by the "Taverne" license above, 
Prof. dr. Maarten Vink Faculteit der Cultuur- en Maatschappijwetenschappen

\section{Elusive citizenship}




\section{Elusive citizenship}

Inaugural lecture for the Chair of Political Science with a focus on Political Sociology

\section{Dr. Maarten Vink}

Faculty of Arts and Social Sciences, Maastricht University

Maastricht, 1 May 2015 


\begin{abstract}
This lecture discusses the contemporary politics of citizenship. Citizenship is an elusive phenomenon as states attach different rights to citizenship and employ different rules for the acquisition and loss of citizenship. How to acquire citizenship and what it means thus depends on the specific context. The significance of citizenship also differs for each person. For example, whereas some immigrants are very interested to naturalize and acquire the citizenship of their new country of residence, others are happy to just keep their original citizenship. In an interconnected world, increasingly more people are citizens of more than one country. However, whereas combating dual citizenship is arguably futile, states continue to deter people from it via restrictive rules. Government -under pressure from skeptical electoratesalso use citizenship status to address problems of immigrant integration or international terrorism, even though citizenship as a legal status is not well suited to address such challenges. Research shows that making the requirements for citizenship more difficult discourages especially those immigrants who are most in need of a secure status. The lecture discusses comparative research on the causes and consequences of citizenship policies and outlines an interdisciplinary research agenda.
\end{abstract}


Mijnheer de Rector, ladies and gentlemen,

\section{Introduction}

Today I would like to talk to you about the elusive nature of citizenship.

The argument, which I will develop in my lecture, is that citizenship eludes individuals, voters and policy-makers. With "elusive" I mean to say: citizenship brings high, but often unrealistic expectations. First, from individuals who are a citizen or aspire to be one; second, from voters who influence the direction of public policies and thus the rules about the acquisition and loss of citizenship; and, third, from policy-makers who use citizenship to respond to societal problems, such as immigrant integration or international terrorism. These high expectations are understandable because citizenship is the most fundamental political status and implies, to speak with Hannah Arendt, 'the right to have rights'.

Yet, we should be careful not to attach too high expectations to citizenship. It is not equipped to tackle the diversity of challenges related to the organization of the 'good life' within political communities. Citizenship, for example, does not prevent racial discrimination. At the same time, making citizenship conditional upon high 'integration requirements', such as passing a language and civic integration test, or asking a very high fee for it, does not guarantee that integration problems will be solved. Making citizenship conditional upon stricter requirements merely makes it a more selective status. As a result, contemporary citizenship laws are frequently subject to amendments, though often without clear or even realistic expectations about what these policy changes can achieve.

In this lecture I will discuss how states regulate the acquisition and loss of citizenship, why they do so differently and what are the consequences of doing so.

Let me illustrate the elusive nature of citizenship with two examples: one of a beauty pageant and another one of a famous actor.

\footnotetext{
${ }^{1}$ Arendt 1994, p. 296.
} 
Ariana Miyamoto is a Japanese beauty pageant who was born to a Japanese mother and an African American father. ${ }^{2}$ She was crowned Miss Japan 2015, but her victory faced criticism from people who verbally abused her for being "haafu". This term is used in Japanese to refer to somebody who is biracial; in other words, somebody who is ethnically only "half" Japanese. Hence, whereas Miyamoto holds Japanese citizenship and speaks fluent Japanese, some people do not think she is "Japanese enough" to represent Japan in the Miss Universe elections this year. ${ }^{3}$

Second, there is the case of Russell Crowe, the well-known actor from movies such as 'Beautiful Mind' and 'Gladiator'. Crowe was born in New Zealand and, according to his Wikipedia entry, ${ }^{4}$ his ancestors were English, German, Irish, Māori, Norwegian, Scottish, Swedish, Welsh, Italian and possibly an Australian convict. While he's a Kiwi, a citizen of New Zealand, when Crowe was four years old his family moved to Sydney, Australia. He moved back to Auckland, New Zealand when he was 14 and back again to Australia when he was 21 and started his acting career. Recently it was reported that Crowe applied for Australian citizenship in 2006 and again in 2013 but was rejected because he failed to fulfill the residency requirements. Due to shooting major motion pictures abroad he would have been away from Australia often and apparently-does not fulfill the residency requirements for naturalization in Australia. In his own words: "I've been voted one of Australia's 50 national treasures. I've even had my face on an Australian stamp, the only non-Australian to do so, apart from the Queen, of course. It's so, so ... unreasonable."5

The cases of Ariana Miyamoto and Russell Crowe, in my view, provide two contrasting illustrations of what I would term "elusive citizenship". Miyamoto is formally is a citizen of Japan, but still faces unequal treatment in practice; Russell Crowe is considered an Australian by many, even had his face on an Australian stamp, but formally is not a citizen of Australia. In other words: citizenship is elusive

\footnotetext{
${ }^{2}$ http://en.wikipedia.org/wiki/Ariana_Miyamoto [last accessed on 25 April 2015].

3 http://www.designntrend.com/articles/45307/20150325/miss-universe-japan-2015-ariana-miyamotoslammed-looking-japanese-enough.htm [last accessed on 25 April 2015].

${ }_{5}^{4}$ http://en.wikipedia.org/wiki/Russell_Crowe [last accessed on 25 April 2015].

5 http://www.theguardian.com/film/2015/mar/25/russell-crowe-twice-denied-australian-citizenship-its- soso-unreasonable [last accessed on 25 April 2015]. However, Australia's Immigration Department said it had no record of any such application by Crowe.
} 
in the sense that even if you have it, you may not be considered a full citizen; whereas even if you don't have it, you may still be treated as equal.

In this lecture, my interest will be especially in the political regulation of the access to citizenship, as well as the rules that govern the loss of it. In other words: under what conditions does one actually acquire citizenship? And how does one loose it?

Over the past decades, one can observe a continuous trend of changes in the laws that regulate the acquisition and loss of citizenship, not only in Europe, ${ }^{6}$ but across the globe. ${ }^{7}$

Let's look, for example, at the Netherlands. This is probably the best example of a country where citizenship law has been continuously in flux.

Figure 1. Changes in Dutch citizenship law since 1985

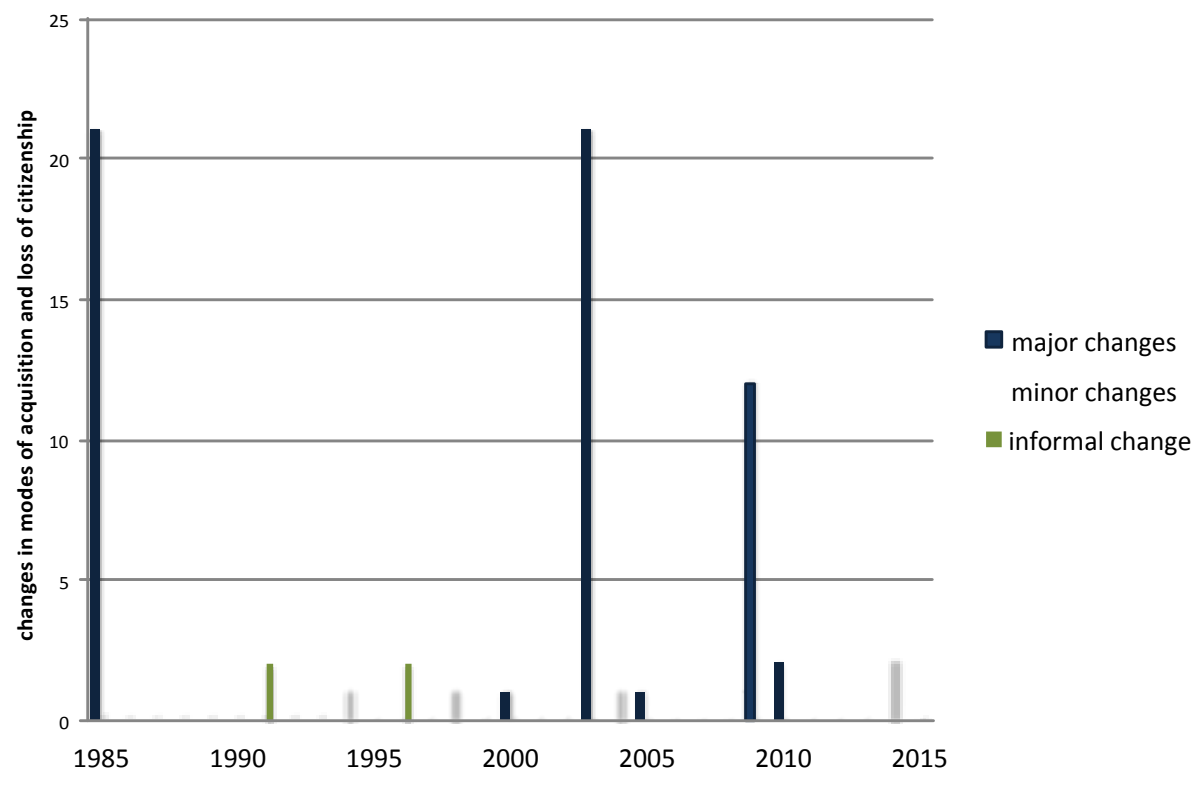

Sources: http://wetten.overheid.nl/BWBR0003738/geldigheidsdatum_31-03-2015/informatie http://eudo-citizenship.eu

\footnotetext{
${ }^{6}$ Hansen and Weil 2001; Bauböck et al 2006.

${ }^{7}$ Aleinikoff and Klusmeyer 2000, 2001.
} 
In Figure 1 you see an overview of the changes in Dutch citizenship law, since 1985. The vertical bars indicate the number of grounds for acquisition and loss of citizenship that were amended in a particular year. The blue bars indicate the major changes. Since 1985, Dutch citizenship law has been revised comprehensively three times: first of all in 1985 with a completely new Nationality Act, then in 2003 with a comprehensive revision and again in 2009. Major and minor legal revisions were introduced in 7 other years. Moreover, one of the most significant amendments to Dutch citizenship policy -the complete toleration of dual citizenship between 1991 and 1996 - was not introduced by law, but by an implementing measure that tolerated dual citizenship in practice. ${ }^{8}$ On average, over the past decades Dutch citizenship law has been altered almost every other year.

Are all these changes really necessary? Is not there too much politics around citizenship? Of course, there may be good reasons to introduce changes to the citizenship law. Think of the need to remove previously discriminatory provisions that biased citizenship law in the Netherlands in favour of men, until recently. ${ }^{9}$ The consequences of this unequal treatment of women were still repaired by amendments to the law as recent as 2010. Other amendments have followed from trends in the modernization of family law, for example with regard to same-sex partnerships. ${ }^{10}$

What has happened -not just in the Netherlands, but more widely- is what I would term the 'instrumentalization' of citizenship law. ${ }^{11}$ Citizenship is viewed as a means (an instrument) to solve perceived societal problems, since the 1990s especially related to immigrant integration and lately also to national security. However, citizenship is not a panacea for all our problems. Instrumentalizing citizenship for policy goals that it is not suitable to address is a self-defeating strategy. Using

\footnotetext{
${ }^{8}$ In 1996, the proposed law that formalized these changes was voted down in the Senate and the restrictive policy came in place again -though since 2003 with substantial exceptions (cf. Vink 2001).

${ }^{9}$ For example, until 1936, in the Netherlands, a Dutch woman who married a foreigner or a stateless person automatically lost her Dutch citizenship. Until 1964, a foreign woman who married a Dutch citizen automatically acquired Dutch citizenship. Until 1985, unless they were born out of wedlock, children acquired Dutch citizenship if the father was Dutch, but not if only the mother was a Dutch citizen. Van Oers et al 2013, p. 8.

${ }^{10}$ See https://zoek.officielebekendmakingen.nl/stb-2004-335.html and https://zoek.officielebekendmakingen.nl/stb-2013-481.html [last accessed on 25 April 2015].

${ }^{11}$ See also Vink and De Groot 2010.
} 
citizenship as integration tool is destined to lead to selective incorporation at best and thus to undermine the very objective it aims to achieve.

This is what I call the 'paradox of elusive citizenship': the more we expect from citizenship, the more hopes we put into it, the less it brings us, the more out of reach it gets.

\section{Citizenship: an elusive status}

So what is citizenship? And what does it get you?

Citizenship (or 'nationality' as it is often termed in international law) in the first place is a legal status that indicates the relation between an individual and a state. Hence, it is an instrument of classification: it is a status that divides persons into two groups: citizens and foreigners. In this sense, citizenship is in itself an empty categorizing concept (speaking with my colleague Rene de Groot), ${ }^{12}$ which only acquires substance within a specific political context. Having citizenship entails legal rights, such as the right to enter your country and to live and work there without restriction, the right to vote, the right to hold political office, among others, as well as duties, such as the obligation to serve in the military.

Some of you may think of citizenship as a passport. However, keep in mind that a passport is primarily a travel document and in itself does not grant any of the rights attached to citizenship. First of all, your passport may have expired, but -luckily- this does not mean that your citizenship has. ${ }^{13}$

Second, passports are sometimes handed out to persons who actually are not citizens of a state. For example, after the First World War, so-called Nansen passports were

\footnotetext{
${ }^{12}$ De Groot 1988.

${ }^{13}$ In the Netherlands, however, the expiry of your passport may be viewed as indication that you no longer are interested in Dutch citizenship and, as a result, when you have lived abroad for more than 10 years, not having renewed your passport may cause the loss of Dutch citizenship -provided you have another citizenship.
} 
issued to refugees from the Russian civil war who had become stateless after Lenin had revoked citizenship for Russian expatriates in $1921 .^{14}$

A third reason for why having a passport should not be equaled to having citizenship, is that some countries differentiate between various types of citizenship statuses. For example, in Latvia, around 260 thousand residents -largely Russophones who arrived in Latvia during the Soviet era between 1940 and 1991- hold the status of 'noncitizen'. These non-citizens, according to Latvian law, are not stateless because they hold the right to reside in Latvia and they are also issued with Latvian passports. However, compared with Latvian citizens, their rights are curtailed: they cannot vote and they cannot hold certain positions in government. These non-citizens are not stateless, but they are not full citizens either. ${ }^{15}$

What are the rights and duties attached to citizenship varies strongly per country. For example, whereas having citizenship normally implies having voting rights, in many countries there are restrictions on the exercise of these rights. Hence, if you are a Dutch citizen who resides in Portugal, you are allowed to vote for the Tweede Kamer elections in the Netherlands. But if you are a citizen of Denmark, for example, you only have the right to vote in national elections if you actually reside in Denmark. ${ }^{16}$ Remarkably, even for elections of the European Parliament (for which all EU citizens have the right to vote), ${ }^{17}$ if you are residing outside your own country, it matters which EU member state you are a citizen of. If you are Dutch, you are fine. If you reside in Portugal you can vote for either Dutch or Portuguese representatives to the EP (but not for both). But if you are Danish and living in Portugal, your rights are restricted: you can only vote for Portuguese representatives. ${ }^{18}$ Whereas European citizens have the same rights, in practice your rights will differ based on which member state you are a citizen of.

\footnotetext{
${ }^{14}$ Later similar travel documents were also issues to Armenian, Assyrian and Turkish refugees. While Nansen passports are no longer issued today, states do grant so-called 'certificates of identity' that may serve as travel document for refugees, stateless persons or persons who have been refused a passport by their own national authorities.

${ }^{15}$ Kruma 2010.

${ }^{16}$ The same applies to Cyprus, Germany, Ireland, Malta, Sweden or the UK, see http://eudocitizenship.eu/electoral-rights/comparing-electoralrights?application=ElectoralRightsNonResident $\& \mathrm{p}=\&$ search $=1 \&$ modeby=ElectionType $\&$ ElectionTyp $\mathrm{e}=$ National+Legislative [last accessed on 25 April 2015].

${ }^{17}$ Article 22(2) TFEU.

${ }^{18}$ Exceptions are civil servants and posted workers.
} 
These are only two examples of how the 'substance' of citizenship, that is: the rights attached to it, differs between jurisdictions. "All men are created equal", to quote the US Declaration of Independence, but no citizenship is the same.

\section{Citizenship policy: trends and configurations}

Now, not only the substance of citizenship varies, but also the rules on how to get it (and how to loose it again, as a matter of fact). This variation makes citizenship highly elusive: a person who would be considered a citizen in one state, under similar circumstances may not be a citizen of another state.

Whereas most persons are citizens of one state only, many are citizens of multiple states and -more problematic- some are a citizen of none. These two traditionally undesirable phenomena -dual citizenship and statelessness- are largely unavoidable anomalies to the international system. This has to do with the premise of national autonomy in determining the rules that govern the acquisition and loss of citizenship, which makes it difficult or even impossible to coordinate rules between states. As a result, some persons benefit from over-inclusive rules, on the one hand, and others suffer from under-inclusive rules.

As the episode of Russell Crowe, illustrates, international migration complicates the regulation of citizenship. Crowe has been denied Australian citizenship on the basis of what he sees as 'unreasonable' grounds. But what are 'reasonable' grounds for the acquisition of citizenship, of course, is open to debate.

Traditionally, states have two options to deal with the consequences of migration: ${ }^{19}$ they can privilege territorial inclusion and attribute citizenship at birth via 'ius soli' (the law of the soil) to all persons born at the territory of a state, or they can privilege ethnocultural inclusion and attribute citizenship at birth via 'ius sanguinis' (the law of the blood) to descendants of citizens. These different principles are sometimes seen as representing 'civic' or 'ethnic' approaches to citizenship. However, in a paper from

\footnotetext{
${ }^{19}$ Weil (2001), pp. 19-21.
} 
2013 co-authored with Rainer Bauböck, ${ }^{20}$ we demonstrate that it would be misleading to conceptualize the variation in citizenship laws along a single 'civic' versus 'ethnic' dimension. In our paper we analyze the citizenship laws of 36 European states on the basis of data collected by the EUDO CITIZENSHIP Observatory.

While an important 'territorial dimension' characterizes citizenship regimes on the basis of provisions on territorial birthright and ordinary naturalization, we show that legal variation cannot be reduced to this single dimension. For a comprehensive analysis of citizenship regimes, indicators of 'ethnocultural' inclusion, such as ius sanguinis and cultural affinity criteria for naturalization, should also be taken into account.

Our analysis also highlights that a limited number of states are characterized by expansive regimes that are inclusive on both dimensions (such as Ireland or Portugal) or, by contrast, insular regimes that are exclusive on both dimensions (such as Austria or Denmark). In other words, citizenship laws configure along two main dimensions, which are driven by different conceptions of inclusiveness. But the two principles are not mutually exclusive.

We demonstrate that these different principles of inclusion lead to variation not only in the rules on the acquisition of citizenship, but also in those on the loss of citizenship. For example, in the Netherlands, citizenship is relatively accessible for foreign-born residents. But it is also relatively easy to lose your Dutch citizenship.

In 2009, five Dutch speed skaters planned to acquire Kazakh citizenship in order to participate in the Vancouver Olympics. Because the Netherlands already has so many good speed skaters, the competition for Olympic tickets is extremely strong. Hence they were invited by the Kazakh Olympic federation to represent Kazakhstan in Vancouver. However, as the five speed skaters discovered, in the Netherlands, if you voluntarily acquire another citizenship, you automatically lose your Dutch citizenship (and the rights attached to it, such as the right to enter and reside in the Netherlands). Even though at least one of them had already become Kazakh national champion at

\footnotetext{
${ }^{20}$ Vink and Bauböck (2013).
} 
the $5 \mathrm{~km}$ distance in 2009, at the last moment they all cancelled the planned naturalization in Kazakhstan after they were warned about the consequences. ${ }^{21}$ The $5 \mathrm{k}$ Kazakh champion from 2010, Jorrit Bergsma, became the 10k Olympic champion for the Netherlands in 2014.

Citizenship is, of course, not just elusive for actors and speed skaters. More and more citizenship is seen as a flexible status ${ }^{22}$ that provides security and can facilitate life in a globalized world. ${ }^{23}$

Consultancy firms such as Henley \& Partners advise global clients about how to obtain a second, or third, passport. Best known are the 'investor citizenship programs' that exist in the Caribbean island nations of St. Kitts and Nevis, for example, where citizenship can be acquired for as little as $\$ 250,000$. In the EU, Cyprus and Malta offer fast-track pathways to citizenship to foreign investors, though these require significantly higher investments, up to several millions. ${ }^{24}$

This flexibility increases the elusiveness of citizenship: it may be more accessible, at some places you can simply buy it, but what does it really mean if citizenship is, indeed, for sale?

As a result of migration, gender equality and more flexible attitudes to dual citizenship, increasingly more people find themselves in a de facto complex citizenship situation.

\footnotetext{
${ }^{21}$ See e.g. http://www.nu.nl/sport/21 18092/naturalisatie-brengt-schaatsers-in-problemen.html [last accessed on 25 April 2015].

${ }^{22}$ Ong 1999.

${ }^{23}$ The website of Henley \& Partners, which provides legal advice on how to obtain an additional passport, provides a good illustration to such an instrumental approach: 'The date of an important business trip is approaching, and you find out that you need a visa. (...) If for some reason you cannot get or renew a passport in your home country (e.g. political instability, civil war, etc.), the right to another passport can be very useful, even critical. Even if you simply lose your passport, it may take some time until you can get a replacement, and having another passport may be crucial. (...) Citizenship may also be a factor in the tie-breaker rules of tax treaties. (...) For good reasons, many international business people and important persons who are active worldwide consider an alternative passport as the best life insurance money can buy.' Source: https://www.henleyglobal.com/whyalternative-citizenship/ [last accessed on 25 April 2015].

${ }^{24}$ Džankić

2015.
} 


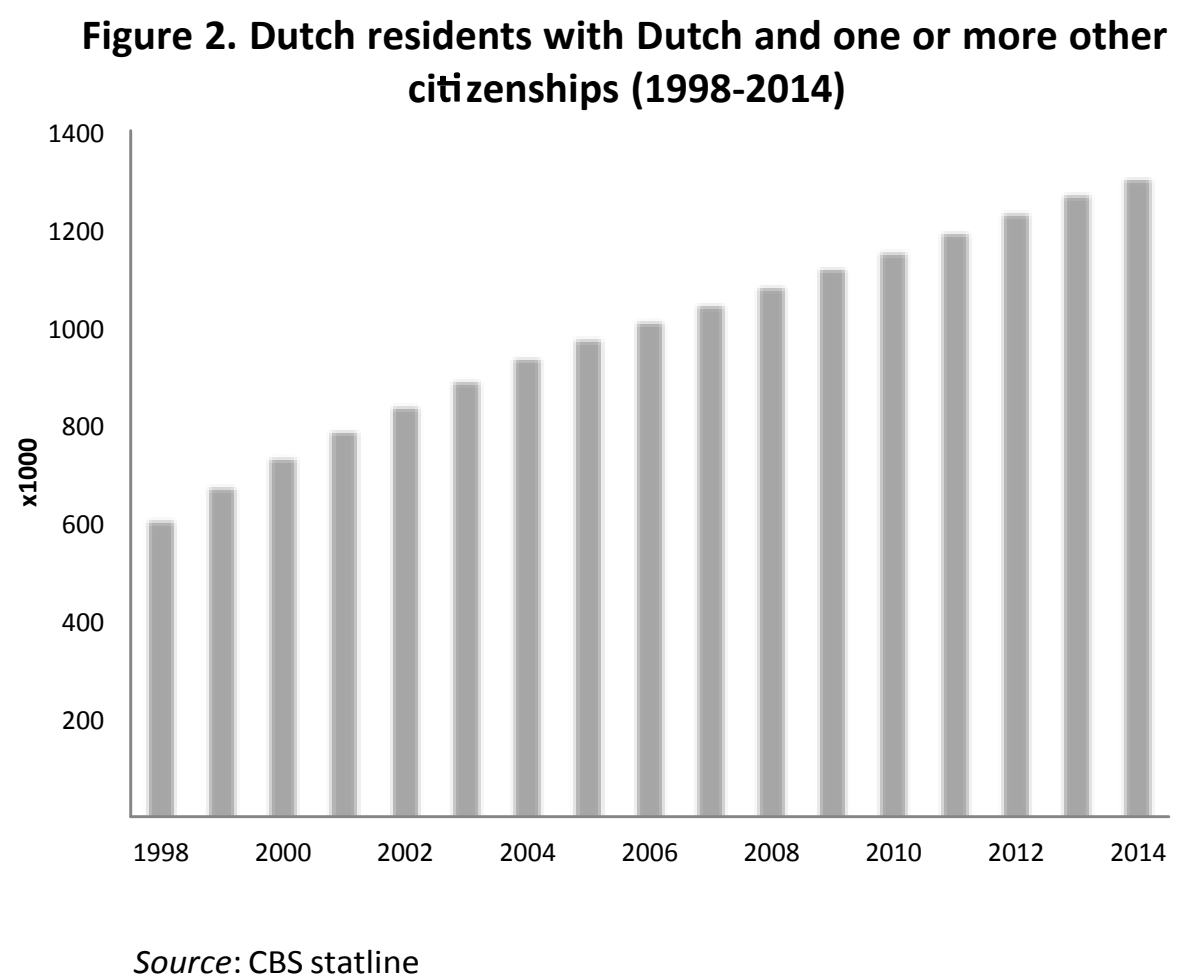

For example, in the Netherlands, immigrants acquiring Dutch citizenship need to renounce their previous citizenship unless they qualify for one of the exceptions. Yet, there are currently around 1.2 million Dutch citizens residing in the Netherlands with dual citizenship (around 7\% of the total population). ${ }^{25}$ This number has doubled since the 1998, after the requirement to renounce one's previous citizenship had been reintroduced (Figure 2). This is because children from parents with different citizenships often automatically acquire dual citizenship. Hence, restrictive naturalization rules cannot stop dual citizenship.

More flexible entry into citizenship is also reflected in greater flexibility with regard to loss of citizenship. Increasingly more states face pressures from expatriates who wish to naturalize in the country where they live. This leads to a trend of more tolerant policies. Based on a novel dataset of expatriate dual citizenship policies since 1960 in over 200 states, collected with Rene de Groot and Chun Luk within the Maastricht Centre for Citizenship, Migration and Development (MACIMIDE), we

\footnotetext{
${ }^{25}$ See e.g. Van Oers et al 2013, on the Dutch context.
} 
find that dual citizenship toleration has increased dramatically over the last half century. $^{26}$

Figure 3. Percentage of states accepting expatriate dual citizenship

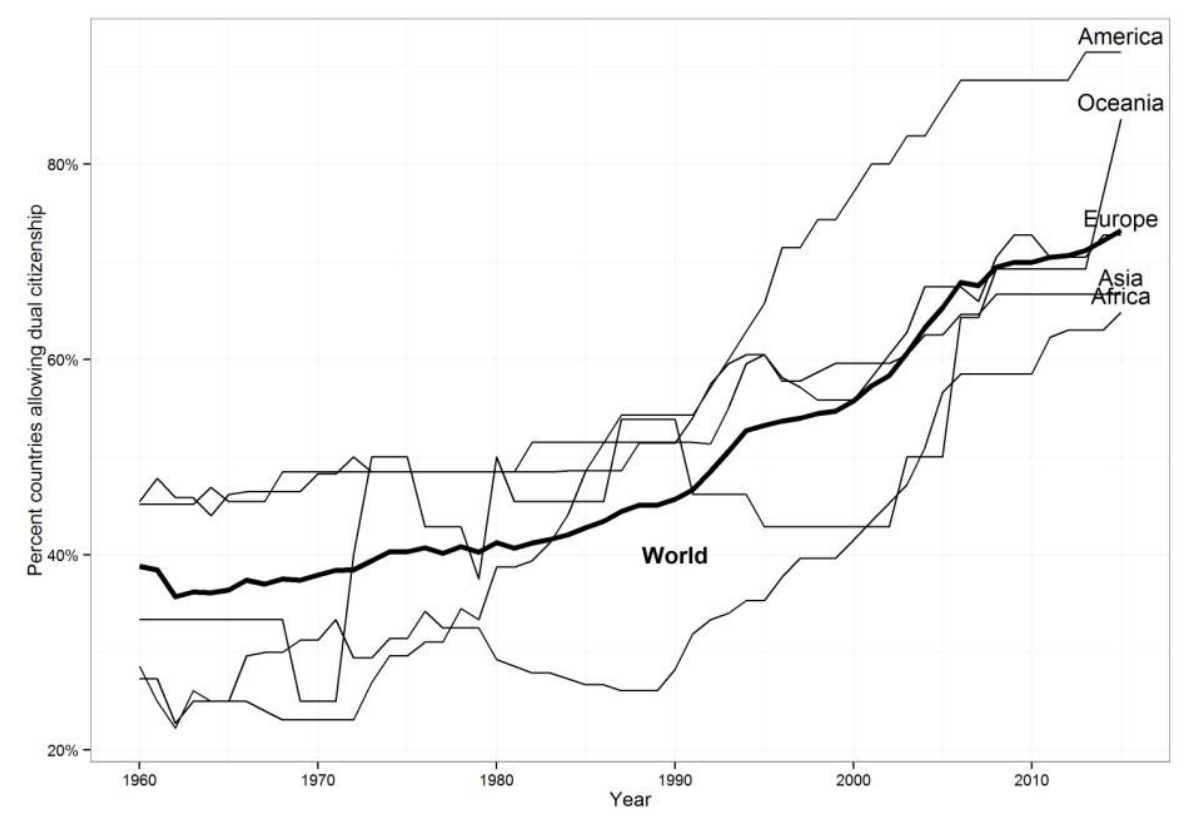

Source: Vink, De Groot and Luk (2015)

Figure 3 shows a strong, nearly linear trend towards acceptance of expatriate dual citizenship. The bold line represents the global trend. While only around a third of all countries that existed in the 1960s accepted dual citizenship, this percentage increases steadily to almost two-thirds of countries in 2015. This trend took place in all regions around the world, though more forcefully in the Americas and less strongly in Asia and Africa. In Europe, the change from restrictive to tolerant attitudes towards dual citizenship precisely follows the global trend. The Netherlands is an exception to this trend. $^{27}$

In a recent paper, co-authored with Arjan Schakel, David Reichel and with De Groot and Luk, we use these data to analyze why the traditionally restrictive dual citizenship

\footnotetext{
${ }^{26}$ Vink, De Groot and Luk (2015).

${ }^{27}$ Note that only 90 of these 200 states continuously existed between 1960 and 2015, but the graph based on these 90 states only looks almost the same, apart from the line for Africa where the acceptance of dual citizenship has gone hand in hand with an increase in the number of independent states.
} 
policies 'survive' in some countries, but not in others. ${ }^{28} \mathrm{We}$ find, first of all, that states that existed since 1960 have a greater than 50\% chance to move from a restrictive to tolerant dual citizenship policy. Second, we find that the propensity to move to a tolerant regime does not depend on size of the country, economic strength, or experience of political violence.

Third, we observe that what matters most is the dual citizenship policy of neighboring countries. If no neighboring country accepts expatriate dual citizenship, then restrictive policies have a 65 percent chance to survive after 50 years; if, however, all neighboring countries accept dual citizenship, the chance for restrictive policies to survive goes down to 20 percent. We call this a 'diffusion' effect, where tolerant policies in states put pressures on those policies in neighboring states.

We hypothesize two underlying mechanisms. First, while fears of dual citizenship continue to exist, they weaken as more countries tolerate expatriate dual citizenship. This is a learning mechanism. Second, emigrant communities are aware of experiences of other groups in migration destination countries and put pressures on policies in neighboring states. This is an emulation mechanism: the international norm of dual citizenship is copied from one state to the other.

Fourth, when we look closer at these processes, we expect that policy diffusion resonates especially within democratic regimes. After all, for electoral reasons, in democracies governments are more sensitive to the demands of expatriate communities and international norms. For non-democracies we find that there is no significant effect of policies of neighboring countries. Rather, it is the size of received remittances that matters for these countries: in other words, for autocratic states, it is money that matters. For democracies, however, the diffusion effect is significant and strong: here, norms matter, more than money.

As a result, legislative attempts to countenance dual citizenship -as in the Netherlands- seem increasingly arbitrary and, arguably, futile. Our data show that the trend is unidirectional and that reverting back to restrictive policies rarely occurs. The

\footnotetext{
${ }^{28}$ Vink, Schakel, Reichel, De Groot and Luk 2015.
} 
pressure from expatriate communities was evident in the successful lobby of the Dutch emigrant community against the proposal of the previous government. Increasing expatriate dual citizenship toleration is a largely self-sustaining phenomenon. $^{29}$

\section{Attitudes towards (dual) citizenship}

If dual citizenship is tolerated for expats, then why not for immigrants? This is a good question and let us now discuss the politics of citizenship a bit further. After all, if citizenship wasn't a highly politicized issue, we would not see such a high degree of volatility in the regulation of it. The Dutch case, again, provides a good example.

\section{Figure 4. Attitudes towards immigrant and emigrant dual citizenship in the Netherlands (2012)}

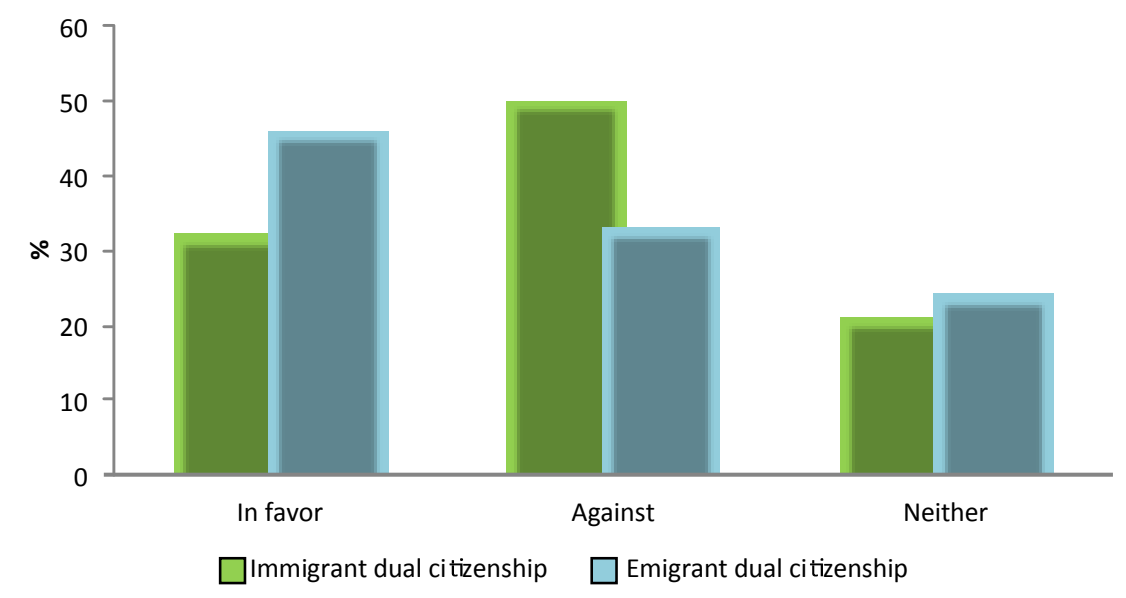

Source: Vink, Gielen \& Schmeets (2015)

Together with Hans Schmeets and Statistics Netherlands, I have investigated attitudes to dual citizenship in the Netherlands. ${ }^{30}$ As part of the Dutch Election Survey in 2010 and 2012, we asked respondents whether they thought that immigrants who naturalize in the Netherlands should be required to renounce their previous citizenship. In 2012, 49 percent of respondents agreed with the renunciation requirement (Figure 4). This

\footnotetext{
${ }^{29}$ Faist et al 2004, 916.

${ }^{30}$ Schmeets and Vink 2011; Vink, Gielen and Schmeets 2015.
} 
means they are against dual citizenship for immigrants. 31 percent disagreed and 20 percent neither agreed, nor disagreed. These percentages were largely comparable in 2010.

When looking at political preferences, unsurprisingly we find that almost all respondents ( 80 percent) who indicate they voted for the PVV, the Freedom Party, hold a negative view on immigrant dual citizenship. Among center-right voters, a bit over 50 percent of voters is against immigrant dual citizenship. In further analyses, we demonstrate that a negative attitude to dual citizenship is linked to perceiving immigration as a cultural threat, to negative views on admission of asylum seekers and to the need for immigrants to assimilate culturally. Hence, skepticism about dual citizenship is connected to fears about migration and its consequences. ${ }^{31}$

In 2012, we also asked respondents for their views on emigrant dual citizenship: should Dutch citizens (such as the speeds skaters I just discussed) who acquire another citizenship be allowed maintain their Dutch citizenship? As you see in the slide, we find that the negative attitudes towards dual citizenship for immigrants are not mirrored when asked for dual citizenship among emigrants: 45 percent of respondents agrees that Dutch citizens naturalizing abroad should be allowed to retain their Dutch citizenship, whereas only 32 percent disagrees with that statement.

The largest discrepancy can be found among Christian-Democratic voters: whereas a majority of these voters is against immigrant dual citizenship (51 percent against, 32 percent in favor), a clear majority is in favor of emigrant dual citizenship (49 percent in favor, 29 against). We also find that our explanatory model for attitudes to dual citizenship (e.g. perceiving immigration as a cultural threat) does not work as well for attitudes to emigrant dual citizenship, as it does for attitudes to immigrant dual citizenship.

In other words, citizenship (especially dual citizenship) also seems to elude voters. These ambiguous views are problematic both legally and normatively. Legally, if one were to require naturalizing immigrants to renounce their previous citizenship, but

\footnotetext{
${ }^{31}$ The largest support in favor of dual citizenship among the major parties is among D66 voters, the Liberal Democrats, where 61 percent of voters supports dual citizenship and only 28 percent is against.
} 
allow Dutch citizens to acquire another, naturalized immigrants would simply reacquire their previous citizenship without penalty. Hence, legally, a mixed approach makes little sense. Normatively, there is no convincing justification for requiring immigrants to renounce their citizenship of origin, but allowing Dutch citizens to naturalize abroad without penalty.

Hence, there is much to say for maintaining the current situation, where the exceptions to the renunciation requirement for naturalizing immigrants in the Netherlands are mirrored in the exceptions on the loss provision applying to Dutch citizens naturalizing abroad. Or -in line with the broader European and global trendto accept dual citizenship altogether. But the data show why this is politically difficult in the Netherlands: voters remain skeptical about dual citizenship, at least for immigrants.

\section{Naturalization outcomes and the citizenship premium}

Now that we have discussed the politics of citizenship, do citizenship policies actually matter? And, if so, for whom and how do they matter?

Let's look at the available statistics about citizenship acquisition in the European Union (EU).

First, around 800 thousand persons per year acquire the citizenship of an EU member state. $^{32}$ These are mostly people who did not get the citizenship of that country when they were born, but acquired this later in life.

Second, while a bit under a million of naturalizations per year may seem a lot, remember that around 500 million people currently live in one of the EU's 28 member states. Of these, there are around 20 million foreign residents $(4 \%) .{ }^{33}$ In

\footnotetext{
${ }^{32}$ http://ec.europa.eu/eurostat/statisticsexplained/index.php/Acquisition_of_citizenship_statistics\#Further_Eurostat_information_[last accessed on 25 April 2015].

${ }^{33}$ See http://ec.europa.eu/eurostat/statistics-

explained/index.php/Population_and_population_change_statistics [last accessed on 25 April 2015]
} 
2012, the average naturalization rate in the EU, calculated as the percentage of foreign resident population that acquires the citizenship of a state, was a bit over $2 \%$. Though this varies greatly between Hungary (almost 13\%) and Slovakia (less than 0.5\%).

\section{Figure 5. Naturalizations in the Netherlands, 1980-2013}

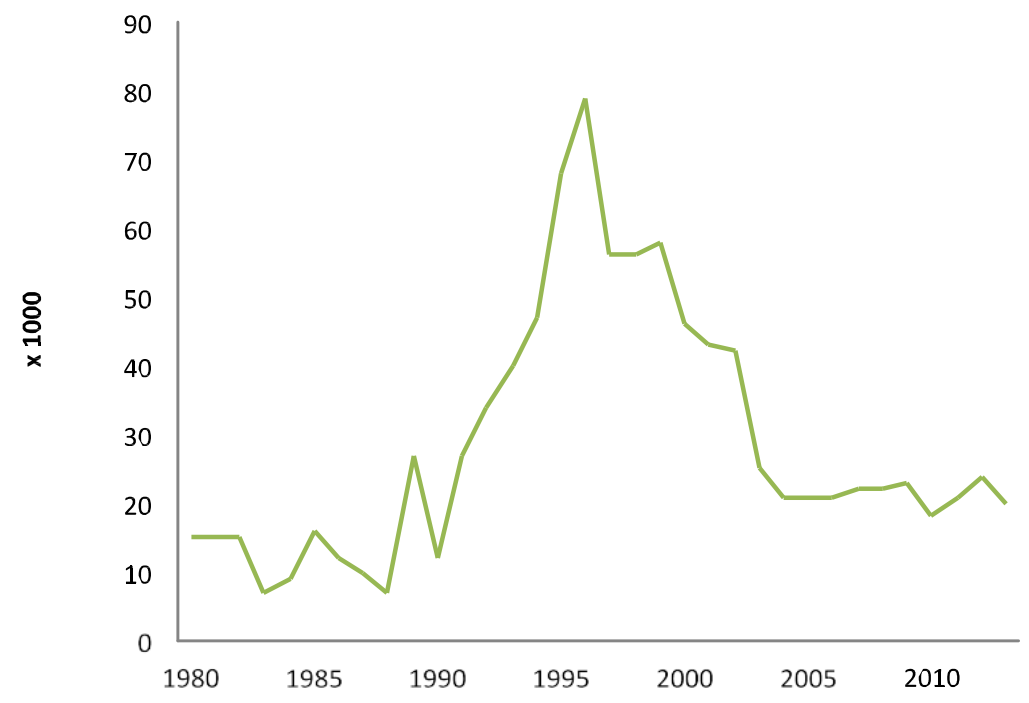

Source: CBS Statline

Third, looking only at a single year obscures the trends in these acquisition rates, which vary greatly over time. In the Netherlands, around $4 \%$ of all resident foreigners acquired Dutch citizenship in 2012. That's around 30.000 people per year. If this seems like a high number to you, keep in mind that in 1996 still 80.000 foreigners acquired Dutch citizenship and that since then the numbers have steadily decreased. Figure 5 visualizes this trend.

For anyone with a bit of knowledge about Dutch citizenship law, it will be selfevident that this trend relates closely to changing requirements for naturalization. First, the strong increase in the number of naturalizations in the 1990s can be directly related to the abolishment of the requirement to renounce one's previous citizenship, between 1991 and 1996. Second, the low number of naturalizations since 2003 can be

andhttp://ec.europa.eu/eurostat/statisticsexplained/index.php/Migration_and migrant_population_statistics\#Foreign_and_foreignborn population [last accessed on 25 April 2015]. 
directly related to the introduction of the naturalization exam in 2003 and the increased fees over the past decades.

However, deriving the effects of policies on naturalization rates is not so straightforward. Aggregate statistics on citizenship, as provided by Eurostat or the national statistical offices, provide a useful overview of main trends, but they are not easily comparable between countries. ${ }^{34}$

Naturalization rates vary not only because of citizenship policies, but also because of factors related to country of origin and the individual life situation of the immigrant. For example, immigrants from more developed countries (from countries with a higher Human Development Index or HDI) have a much lower probability to naturalize than those from the least developed countries. ${ }^{35}$ Whereas most immigrants from the least developed countries tend to naturalize, only 20 percent of those from the most developed countries naturalize. From other research we know that also the political stability and the dual citizenship regulations of an origin country matter. ${ }^{36}$

In other words, when analyzing immigrant naturalization rates, it is important to have information on the demographic composition of the immigrant population of a country.

In a 2013 paper with Tijana Prokic and Jaap Dronkers we control statistically for these differences in the demographic composition of migrant populations and for the relative accessibility of citizenship. For that we used an indicator produced by the Migrant Integration Policy Index (MIPEX). The 2015 version of MIPEX has just been

\footnotetext{
${ }^{34}$ Reported statistics do not always refer to similar categories of persons across member states (Poulain, Perrin and Singleton 2006). See also Regulation (EC) No 862/2007 of the European Parliament and of the Council of 11 July 2007 on Community statistics on migration and international protection and repealing Council Regulation (EEC) No 311/76 on the compilation of statistics on foreign workers [2007] OJ L 199, pp. 23-29. Comparative citizenship statistics are even more problematic with regard to statistics on the loss of citizenship, as demonstrated in a report with Chun Luk as part of the EU-sponsored ILEC project. See Vink and Luk (2014).

${ }^{35}$ Vink, Prokic-Breuer and Dronkers (2013).

${ }^{36}$ Moreover, it makes a difference how long on immigrants reside in a country, whether they are for example married to a native or to a foreign-born resident who has already naturalized, whether the immigrant has children, etcetera. Cf. Yang (1994), Dronkers and Vink (2012).
} 
launched by the Migration Policy Group in Brussels. ${ }^{37}$ We found that -indeedcitizenship policies do matter. However, they matter most for the migrants who are most in need of citizenship, namely those from less developed countries. On average, whereas only $20 \%$ of immigrants in the most restrictive countries naturalize if they have lived there between 6 to 10 years, almost $60 \%$ naturalizes in those countries with the most accessible laws. For immigrants from highly developed countries, policies do not matter: their naturalization rates are much lower and citizenship acquisition is mostly a function of length of residence in the destination country.

Of course, as we already saw in the Netherlands, countries do not have stable accessible or restrictive citizenship policies. Policies change, sometimes opening up citizenship, as Portugal did in 2006, sometimes restricting it, as the Netherlands did in 2003. In the literature, there is surprisingly little interest in the effects of these policy changes, even though this is the question with the greatest policy relevance. Often, it is assumed that policy restrictions lower naturalization rates. But actually we know little about the question for whom these restrictions matter most and how much.

In research I currently do with Floris Peters and Hans Schmeets, supported by MACIMIDE and Statistics Netherlands, we analyze population register-data from the Netherlands over the period since 1995. In this analysis we look at foreign-born residents in the Netherlands and include statistical controls for origin country and individual characteristics of immigrants.

We find that the restriction of Dutch citizenship law in April 2003 had a significantly negative impact on immigrant naturalization rates. ${ }^{38}$ Among immigrants who arrived in Netherlands in 1995, 1996 or 1997 on average 58 percent is naturalized after 10 years. Yet, among cohorts from 2000, 2001 and 2002, only 42 percent was naturalized after a similar period. These differences are even greater if you look at those groups who are most in need of citizenship, such as immigrants from less developed

\footnotetext{
${ }^{37}$ In order to statistically measure the impact of varying in citizenship policies, we also need precise and reliable indicators for the relative accessibility of citizenship laws. These are provided, for example, by the Migrant Integration Policy Index (MIPEX), which is produced by the Migration Policy Group in Brussels. Access to citizenship can be measured by looking at the years of residence required before naturalization, the fees, the integration exam and the requirement to renounce one's previous citizenship, for example. See http://www.mipex.eu [last accessed 25 April 2015].

${ }^{38}$ Peters, Vink and Schmeets 2015.
} 
countries.

We compare immigrants from cohorts that could still naturalize under the pre-2003 legislation and those who could only do so under the stricter 2003 law. We find that for immigrants from highly developed countries the propensity to naturalize is virtually the same between cohorts that fall under the pre and post 2003 legislation. However, for immigrants from less developed countries, the difference is significant: immigrants from cohorts that fall under the stricter 2003 legislation naturalize later and less often.

In other words: we see that policy does matter, especially for those immigrants who are most interested in acquiring citizenship of the country in which they live. It is not just that, under the 2003 law, these immigrants postpone naturalization, they seem to be put off altogether. And if you argue that this was precisely what was intended, I would disagree. The 2003 changes to the Dutch citizenship law, including the naturalization exam, were motivated by a political agenda of failed integration policies. Hence the changes were aimed at improving immigrant integration. Yet, the result of these changes, as the analysis shows, was only a more selective access to citizenship. The Dutch case shows how the instrumentalization of citizenship policies makes citizenship not less, but more elusive, for large groups of immigrants.

One last issue I would like to discuss with you is whether it matters how fast immigrants naturalize. This question is relevant in light of the proposal by the current government in the Netherlands to increase the residence requirement for ordinary naturalization from 5 to 7 years. ${ }^{39}$ The assumption is that immigrants who naturalize later will be better integrated at the moment of naturalization. Hence, naturalizing later is better. But is that so...?

First of all, actually we know surprisingly little about whether it matters if immigrants naturalize faster or slower. This is because most of the literature is focused on analyzing whether naturalization maters, rather than on finding out why, how and for whom it matters.

\footnotetext{
${ }^{39}$ Wijziging van de Rijkswet op het Nederlanderschap ter verlenging van de termijnen voor verlening van het Nederlanderschap en enige andere wijzigingen, Voorstel van Rijkswet, 33852 (R2023), Nr. 2.
} 
Bevelander and DeVoretz have recently argued that a fast-track to citizenship can maximize the potential for settlement success, although too short a waiting period before naturalization can diminish its potential. ${ }^{40}$ Their reasoning is that citizenship acquisition by immigrants can have a premium on the labor market (better employability, higher income) because it sends a positive signal to employers about the long-term settlement in the country. After a very short period (for example 2 or 3 years), they argue that the 'accumulated country-specific human capital' (education, knowledge of labor market, language) is still minimal. Hence, with a very short residence requirement, the citizenship ascension rates are high, many immigrants may naturalize, but the labor market pay-off of doing so will be minimal.

However, if the waiting period for citizenship becomes too long, on the other hand, the citizenship premium inevitably declines. Naturalized immigrants simply have fewer years to profit from a positive signal vis-à-vis employers, if they naturalize after a longer waiting time. Hence there will be less incentive for immigrants to accumulate human capital while waiting for citizenship. ${ }^{41}$

With Tijana Prokic-Breuer and Jaap Dronkers, I did some preliminary analysis on the question of whether the speed of naturalization matters. ${ }^{42}$ We used data from the European Labour Force Survey (Ad hoc module on Labour Market Situation of Migrants) from 2008 and analyzed the relation between speed of naturalization and the probability of having paid employment, among immigrants. We controlled for individual and country of origin characteristics.

While the picture is mixed, we found that in Belgium, the Netherlands and Germany there is a negative correlation between years of residence until naturalization, on the one hand, and the probability of having paid employment, on the other. This suggests that immigrants who naturalize later, perform less well on the labor market. Hence we do not find support for the argument that it is better for immigrants to naturalize after

\footnotetext{
${ }^{40}$ Bevelander and DeVoretz 2014.

${ }^{41}$ Moreover, if citizenship becomes out of reach, then this may stimulate outmigration of economically capable candidates for citizenship. Research in Germany has demonstrated that indeed naturalized immigrants are less likely to out-migrate (Kuhlenkasper and Steinhardt 2012).

${ }^{42}$ Prokic-Breuer, Dronkers and Vink 2013.
} 
a longer residence period only, at least not in the Netherlands. If anything, the data suggest the opposite: the faster an immigrant naturalizes, the higher the citizenship premium on the labor market.

From this perspective, there are good reasons to caution against the government proposal that is currently under discussion in the Netherlands. As Bevelander and DeVoretz argue, a longer pathway essentially leads to lower naturalization rates and it reduces the possibility for immigrants to make use of the positive potential of citizenship. $^{43}$

However, we should be careful when interpreting these preliminary findings. First, in three other countries we found no relation and in one country, the UK, we found the opposite relation. Hence, as is often the case in this type of research, results vary by country. This may be explained, for example, by the structure of labor markets in the UK and Continental Europe. For this reason, more comparative research is needed to investigate this relationship under various institutional conditions.

Second, in order to analyze whether naturalization makes a difference, one needs to draw on longitudinal data, rather than the cross-sectional survey data we used in our exploratory analysis. Longitudinal data, for example those we employ in the MACIMIDE research project with Floris Peters and Hans Schmeets, based on Dutch register-data, allow us to detect whether citizenship acquisition actually improves labor market outcomes or whether, by contrast, better integrated immigrants are simply more likely to naturalize. These results we hope to share within the next year. Moreover, further comparative research is required to compare such findings from the Netherlands with those from other countries, based on similar types of high quality register data. This is something I plan to work on in the coming years, especially with colleagues from Scandinavian countries where similar type of register-data are available as in the Netherlands. So there's more work still to do in this field...

\footnotetext{
${ }^{43}$ In its advice on the draft law, the Dutch Council of State observed that a clear motivation for this restriction is missing and if no such motivation can be provided, the proposed amendment should be withdrawn. Wijziging van de Rijkswet op het Nederlanderschap ter verlenging van de termijnen voor verlening van het Nederlanderschap en enige andere wijzigingen, Advies Afdeling Advisering Raad van State van het Koninkrijk en Nader Rapport, 33852 (R2023), Nr. 4.
} 


\section{A political sociology approach: interdisciplinary and comparative}

Let me sum up my main argument:

- Citizenship is an elusive concept: it is both everything and nothing. By defining its permanent population, citizenship is an important constituent element of the modern nation-state. Yet, its meaning depends on the context in which it is practiced: states attach different rights to citizenship and each state employs different rules for the acquisition and loss of citizenship. Hence, citizenship is an important status that can, however, mean different things.

- Citizenship eludes policy-makers and voters: states have autonomy to regulate the access to citizenship; yet, in an interconnected world, policies in one country do affect outcomes in other countries. Moreover, phenomena that were previously considered undesirable, such as dual citizenship, become increasingly unavoidable. Hence, we see the acceptance of dual citizenship gradually spreading across the world. Policy-makers in states with restrictive policies, such as the Netherlands, are increasingly under pressure from their emigrant community to loosen these rules. At the same time, domestic electorates provide a counterbalance, pushing for restrictive policies as in the Netherlands, where attitudes towards citizenship are ambiguous, with dual citizenship tolerated for one group (emigrants), but not for others (immigrants).

- Citizenship also eludes individuals: varying naturalization rates demonstrate that citizenship has different meanings to different persons: some immigrants may be able to naturalize, but they are not interested in doing so; for others, however, acquiring citizenship of a developed country provides a potentially life-changing event. Yet restrictive rules and high costs do discourage people from naturalizing and are most discouraging for those who need citizenship most. Citizenship is elusive and its instrumentalization for political agendas makes it even more so.

To conclude, I would like to say a few words about the "Chair of Political Science with a focus on Political Sociology", which I accept today with this public lecture, and my research agenda for the coming years. 
As one of my two $\mathrm{PhD}$ supervisors at Leiden University, Herman van Gunsteren, already observed back in 1978 , citizenship as a concept is essentially contested. ${ }^{44}$ Its meaning depends on ideological view point and on the context in which it is practiced. Hence, citizenship is elusive by its nature and requires versatility from us as analysts in two important ways: while interdisciplinarity is required to capture the multiple dimensions of the concept of citizenship, a comparative approach is essential to capture its contingency.

Now, this is easier said than done. If there is one thing I have come to realize over the past years, through research but also teaching experience, it is that inter-disciplinarity does not come cheap.

For the citizenship research agenda I outlined today, analyzing the causes and consequences of citizenship policies, this means that you need to be a lawyer, political scientist, sociologist and economist at the same time. After all, we need law to collect and interpret information about national laws in light of constitutional and international law standards. But how these laws come about, is a different matter. This is where political science comes in. And how they affect naturalization rates and labour market outcomes among immigrants, that's where we need sociologists and economists. And, finally, I should not forget normative theorists, for a reflection on how citizenship should be governed.

Now, whereas these different questions can of course be studied separately, a truly inter-disciplinary research agenda approaches these questions in an integrated manner. First of all, this is important because without valid data on citizenship law, statistical analyses on developments in citizenship policies, or on the effects of policies on naturalization rates, would be impossible. Second, an analysis of naturalization rates or integration outcomes also requires a systematic understanding of the institutional context. If there is one thing you can observe in the thriving literature on the question of whether citizenship matters for immigrant integration, it is that results of different studies often differ greatly. For some this is an argument

\footnotetext{
${ }^{44}$ Van Gunsteren 1978; cf. Gallie 1956.
} 
that citizenship, in the end, does not really matter. But for me this just means that there is underlying contextual variation that we do not yet understand well. Hence, sociologists and economists benefit from collaboration with lawyers and political scientists.

The sub-discipline of political sociology, which involves the systematic study of the relations between state and society, offers such a bridge between political science and sociology. My own research, as presented today, illustrates what an interdisciplinary political sociology approach can contribute to citizenship studies.

I see it as a core responsibility of this Chair to further interdisciplinary and comparative research on political sociology themes, such as migration and citizenship, but also on broader themes within European Studies, within the Faculty of Arts and Social Sciences (FASoS) and at Maastricht University at large. This means building bridges, both within my own faculty and between faculties. As I hope to have demonstrated today, such bridges offer a chance to overcome the constraints of narrow disciplinary approaches. A successful political sociology agenda for citizenship, which is based on fundamental research and is policy-relevant, needs to be both comparative and interdisciplinary. Citizenship may be elusive, but there are ways of dealing with that. 


\section{Acknowledgements}

To conclude this lecture, a few -but important- words of gratitude. First of all, I would like to thank Maastricht University for its trust in me with this appointment as professor of political science and political sociology. This is truly an honor.

Within the Faculty of Arts and Social Sciences, I am very thankful to Rein de Wilde and Sophie Vanhoonacker for supporting my appointment. Without your support I would not stand here today. My gratitude extends to the whole Faculty, where I have felt welcome since starting here back in 2004. It is an extremely rewarding place to work.

At Maastricht University at large, I would like to thank my colleagues Rene de Groot, Valentina Mazzucato, Hildegard Schneider and Melissa Siegel, of the Executive Board of the Maastricht Center for Citizenship, Migration and Development (MACIMIDE), as well as Costica Dumbrava, for their cooperative spirit in setting up and expanding this joint initiative. I have spoken before about the importance of cooperation across academic disciplines and believe that our efforts to pool resources from various faculties, with the important support of the UM's Executive Board, have been extremely productive so far. I look forward to working with you within the new ITEM project, establishing the Institute on Transnational and Euregional CrossBorder Cooperation.

I would like to devote a special 'thank you' to René de Groot, professor of Comparative Law and Private International Law at this University, who has been extremely supportive of my work, ever since I visited Maastricht from Leiden during my $\mathrm{PhD}$ research in the early 2000s to discuss the Micheletti case and other developments in the area of nationality law (while enjoying an excellent lunch, if I remember well, which struck me as visitor from the Calvinist Western part of the country). Meanwhile we have co-authored several works together and it is simply a delight to work together. Thanks also to Olivier Vonk for joining some of these 'coproductions'. 
Two other UM colleagues I would like to mention. First, Jaap Dronkers, professor of International comparative research on educational performance and social inequality. Jaap, unfortunately, could not be here today but his infectious enthusiasm for sociological research has contributed much to the research agenda I presented here today. Then, Hans Schmeets, professor of Social Statistics at my Faculty, and also at Statistics Netherlands, with whom I have collaborated on some of the projects discussed earlier and I look forward to continue working on many new 'big data' initiatives.

Beyond Maastricht, I would like to acknowledge my great appreciation for the presence today of professor Jo Shaw of Edinburgh University and professor Rainer Bauböck of the European University Institute. Jo and Rainer, it is a true privilege to co-direct the European Union Democracy Observatory on Citizenship with you and I am delighted both of you could make it here today. EUDO CITIZENSHIP by now has firmly established itself as the go-to place for information about developments related to citizenship. Our Observatory keeps on expanding, thematically and geographically, and is a prime example of how much can be established with relatively limited, but significant support from European and national funding agencies. Much of the work depends on our large network of country experts in over 70 countries in Europe and, since recently, also the Americas. Thanks also to the Robert Schuman Centre for Advanced Studies at the EUI in Florence, for facilitating my work as co-director through a part-time professorship.

Aside from academia, thanks to friends and family for joining me here today. It is a special day and I'm happy you are here to listen and, in a moment, to celebrate. I am grateful to my parents for their love and support. Dankjewel. And, last but not least, to Patrícia, for showing me that something as elusive as love can still be very tangible.

Ik heb gezegd. 


\section{References}

Aleinikoff, A. and D. B. Klusmeyer, Eds. (2000). From Migrants to Citizens : membership in a Changing World. Washington, Carnegie Endowment.

Aleinikoff, A. and D. B. Klusmeyer, Eds. (2001). Citizenship Today: Global Perspectives and Practices. Washington, Carnegie Endowment.

Arendt, H. (1994). The Origins of Totalitarianism. New York: Harcourt Books.

Bauböck, R., E. Ersbøll, K. Groenendijk and H. Waldrauch, Eds. (2006). Acquisition and Loss of Nationality: Policies and Trends in 15 European States : Comparative Analyses. Amsterdam, Amsterdam University Press.

Bauböck, R. (1994) Transnational Citizenship. Aldershot: Edward Elgar.

Dzankic, J. (2015), Investment-Based Citizenship and Residence Programmes in the EU. Robert Schuman Centre for Advanced Studies Research Paper No. RSCAS 2015/08. Available at SSRN: http://ssrn.com/abstract=2558064.

De Groot, G.-R. (1988). Staatsangehorigkeitsrecht im Wandel. Eine rechtsvergleichende Studie über Erwerbs- und Verlustgründe der Staatsangehorigkeit, Keulen, Karl Heymanns.

De Groot, G.-R. (2008). Nationaliteit en rechtszekerheid. Boom.

De Groot, G.R. and M. Vink (2010). Loss of Citizenship: Trends and Regulations in Europe. Comparative Report RSCAS/EUDO-CIT-Comp. 2010/4. Florence: EUDO Citizenship Observatory, pp. 52.

Dronkers, J. and M. Vink (2012). Explaining Access to Citizenship in Europe: How Policies Affect Naturalisation Rates. European Union Politics 13(3) 390-412.

Faist, T. (2004). Dual Citizenship as Overlapping Membership. International Migration in the New Millennium. D. Joly. Aldershot, Ashgate: 210-231.

Gallie, W.B. (1956). Essentially Contested Concepts. Proceedings of the Aristotelian Society, 56: 167-198.

Hansen, R. and P. Weil (2001). Introduction: Citizenship, Immigration and Nationality : Towards a Convergence in Europe? In: R. Hansen and P. Weil , Eds, Towards a European Nationality: Citizenship, Immigration and Nationality Law in the EU. Basingstoke, Palgrave: 1-23.

Krūma, K. (2010). Country Report: Latvia. Florence: EUDO Citizenship Observatory. Ong, A. (1999). Flexible Citizenship: The Cultural Logics of Transnationality. Durham: Duke University Press. 
Peters, F., M. Vink and H. Schmeets (2015). The ecology of immigrant naturalization: a life course approach in the context of institutional conditions. Journal of Ethnic and Migration Studies [advance online publication]. Available at: http://dx.doi.org/10.1080/1369183X.2015.1103173.

Poulain, N, N. Perrin and A. Singelton, Eds (2006). Towards Harmonised European $\underline{\text { Statistics on International Migration. Louvain-la-Neuve, UCL Presses }}$ Universitaires de Louvain.

Prokic-Breuer, T., J. Dronkers and M. Vink. The Faster, the Better? Speed of Naturalisation and Socio-economic integration of Immigrants in Europe. Den Haag: Ministerie van Veiligheid \& Justitie, 6 June 2013.

Schmeets, H. and M. Vink (2011). Opvattingen over dubbele nationaliteit en de minderhedenproblematiek. In H. Schmeets, ed., Verkiezingen: Participatie, Vertrouwen en Integratie. Heerlen: Centraal Bureau voor de Statistiek, Ch. 7.

Van Gunsteren, H. (1978) Notes on a theory of citizenship. In P. Birnbaum, J. Lively and G. Parry (eds) Democracy, Consensus \& Social Contract. London: SAGE, pp. 9-35.

Van Oers, R., B. de Hart and K. Groenendijk (2013). Country report: The Netherlands. Florence: EUDO CITIZENSHIP Observatory.

Vink, M., T. Prokic-Breuer and J. Dronkers (2013). Immigrant Naturalization in the Context of Institutional Diversity: Policy Matters, But to Whom? International Migration 51(5) 1-20.

Vink, M. and R. Bauböck (2013). Citizenship Configurations: Analysing the Multiple Purposes of Citizenship Regimes in Europe. Comparative European Politics, 11(5) 621-648.

M. Vink, W. Gielen and H. Schmeets (2015). Opvattingen over dubbele nationaliteit. In H. Schmeets, ed., Nationaal Kiezersonderzoek 2006-2012. Heerlen: Centraal Bureau voor de Statistiek, pp. 77-93.

Vink, M. and G.R. de Groot (2010). Citizenship Attribution in Western Europe: International Framework and Domestic Trends. Journal of Ethnic and Migration Studies, 36(5) 713-734.

Vink, M.P., G.-R de Groot and N.C. Luk (2015). MACIMIDE Global Expatriate Dual Citizenship Dataset. Harvard Dataverse, V2. Available here.

Vink, M. and C. Luk (2014). Mapping Statistics on Loss of Nationality in the EU: Introducing a New Online Database. Background paper for ILEC-project (project 
on Involuntary Loss of European Citizenship), CEPS Paper in Liberty and Security in Europe, No. 76.

Vink, M. (2001). The Limited Europeanization of Domestic Citizenship Policy: Evidence from the Netherlands. Journal of Common Market Studies 39(5) 875896.

Weil, P. (2001). Access to Citizenship: comparison of 25 nationality laws. In T. Aleinikoff and D. Klusmeyer, Eds. Citizenship today: global perspectives and practices. Washington, DC, Carnegie Endowment.

Yang, P. Q. (1994). Explaining Immigrant Naturalization. International Migration Review 28(3): 449-477. 